\title{
Abnormal enhancement of light output by cation mixing in $\mathrm{Zn}_{x} \mathrm{Mg}_{1-x} \mathrm{WO}_{4}$ nanocrystals
}

\author{
I.A.Tupitsyna ${ }^{1}$, P.O.Maksimchuk ${ }^{1}$, A.G.Yakubovskaya ${ }^{1}$, \\ A.M.Dubovik ${ }^{1}$, V.V.Seminko ${ }^{1}$, V.S.Zvereva ${ }^{1}$, O.G.Trubaeva ${ }^{1}$, \\ K.O.Hubenko ${ }^{1}$, O.M.Vovk ${ }^{2}$, Y.V.Malyukin ${ }^{1}$
}

${ }^{1}$ Institute for Scintillation Materials, STC "Institute for Single Crystals", National Academy of Sciences of Ukraine, 60 Nauky Ave., 61001 Kharkiv, Ukraine ${ }^{2}$ Institute for Single Crystals, STC "Institute for Single Crystals", National Academy of Sciences of Ukraine, 60 Nauky Ave., 61001 Kharkiv, Ukraine

\section{Received January 24, 2017}

In the paper the effect of light output increase with maximum at $x=0.5$ observed previously for the mixed $\mathrm{Zn}_{x} \mathrm{Mg}_{1-x} \mathrm{WO}_{4}$ crystals is demonstrated for nanocrystals with the same composition. The enhancement of light output up to 3 times at the transition from bulk to nanosize was shown. This effect is determined by nonlinear dependence of concentration of oxygen vacancies with minimum at $x=0.5$ for $\mathrm{Zn}_{x} \mathrm{Mg}_{1-x} \mathrm{WO}_{4}$ nanocrystals.

Keywords: mixed $\mathrm{Zn}_{x} \mathrm{Mg}_{1-x} \mathrm{WO}_{4}$ crystals, light output.

Установлено, что эффект увеличения светового выхода, наблюдаемый в смешанных объемных кристаллах $\mathrm{Zn}_{x} \mathrm{Mg}_{1-x} \mathrm{WO}_{4}$, с максимумом при $x=0,5$, обнаружен у нанокристаллов такого же состава. Показано аномальное усиление этого эффекта в 3 раза при переходе к наноразмерам. Это обусловлено наблюдаемой нелинейной зависимостью концентрации кислородных вакансий в зависимости от соотношения катионов цинка и магния в нанокристаллах $\mathrm{Zn}_{x} \mathrm{Mg}_{1-x} \mathrm{WO}_{4}$.

Аномальне підвищення світлового виходу у змішаних нанокристалах $\mathbf{Z n}_{x} \mathbf{M g}_{1-x} \mathbf{W O}_{4}$. І.А.Тупіцина, П.О.Максимчук, Г.Г.Якубовська, О.М.Дубовик, В.В.Семінько, В.С.Звєрєва, О.Г.Трубаєва, К.О.Губенко, О.М.Вовк, Ю.В.Малюкін.

Встановлено, що ефект збільшення світлового виходу, що спостерігається

у змішаних об'ємних кристалах $\mathrm{Zn}_{\chi} \mathrm{Mg}_{1-\chi} \mathrm{WO}_{4}, 3$ максимумом при $x=0,5$, виявлений у нанокристалів такого ж складу. Показано аномальне підсилення цього ефекту в 3 рази при переході до нанорозмірів. Це обумовлено нелінійною залежністю з мінімумом при $x=0,5$ концентрації кисневих вакансій в залежності від співвідношення катіонів цинку і магнію у нанокристалах $\mathrm{Zn}_{x} \mathrm{Mg}_{1-x} \mathrm{WO}_{4}$.

\section{Introduction}

Scintillators based on tungstate single crystals are widely used in detectors and spectrometric systems for nuclear physics and nuclear power engineering, geology and medicine, as well as in various devices of radiation control [1-3]. Recently it was shown that an increase in light output can be achieved by turning from pure compounds to solid solutions, so-called mixed crystals. This effect has recently been demonstrated for some of the compounds [4-7], including $\mathrm{Zn}_{x} \mathrm{Mg}_{1-x} \mathrm{WO}_{4}$ bulk mixed crystals $[8,9]$, but the nature of this effect remained obscure until now. In this paper we 

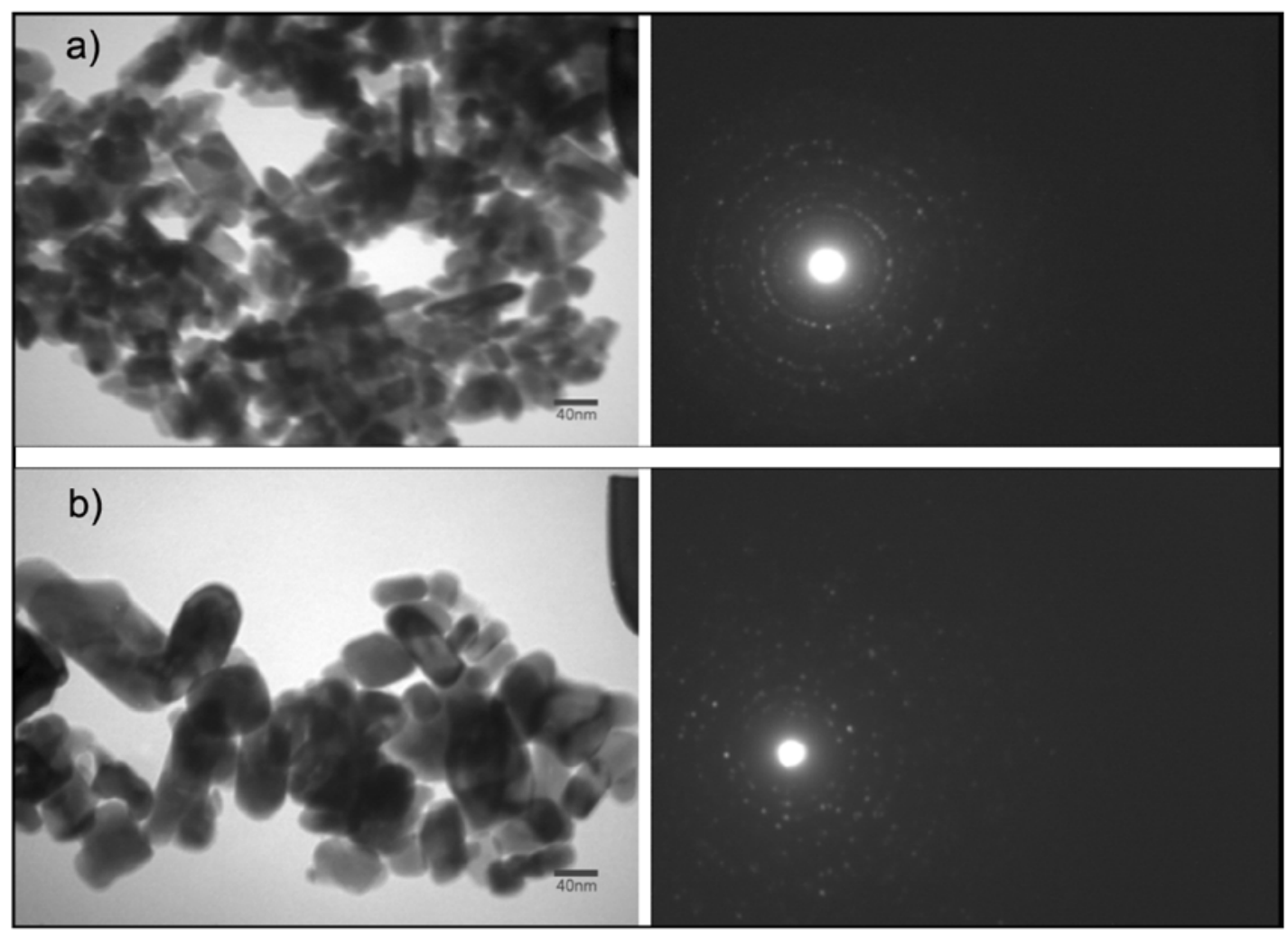

Fig. 1. TEM-image and diffraction pattern of $\mathrm{ZnWO}_{4}$ (a), $\mathrm{Zn}_{0.5} \mathrm{Mg}_{0.5} \mathrm{WO}_{4}$ (b).

investigated the luminescent properties of $\mathrm{Zn}_{x} \mathrm{Mg}_{1-x} \mathrm{WO}_{4}$ crystals and nanocrystals. It was expected that by transition to nanoscale scintillation materials improving certain functional characteristics (sensitivity, spatial, and temporal resolution, radiation strength, afterglow) would become possible [10-14] as well as extending their applications [15-18]. Indeed, despite the fact that Onsager radius of these materials is about $5 \mathrm{~nm}$, and therefore, the direct effect of the size of the nanocrystal on the processes of recombination of electron-hole pairs is absent, the scintillation processes in nanocrystals differ significantly as compared with their bulk counterparts.

\section{Experimental}

$\mathrm{Zn}_{x} \mathrm{Mg}_{1-x} \mathrm{WO}_{4}$ single crystals with different compositions were grown by Czochralski method, the charge was obtained by solidphase synthesis of $\mathrm{ZnO}(99.995 \%)$, MgO $(99.95 \%)$ and $\mathrm{WO}_{3}(99.995 \%)$ [8, 9]. $\mathrm{MgWO}_{4}$ single crystal was grown from melted flux solution by pulling on a rotating seed [19].

$\mathrm{Zn}_{x} \mathrm{Mg}_{1-\chi} \mathrm{WO}_{4}$ nanocrystals were produced using the method of liquid-phase synthesis, followed by crystallization in molten $\mathrm{LiNO}_{3}$.
Amorphous $\mathrm{Zn}_{x} \mathrm{Mg}_{1-x} \mathrm{WO}_{4}$ samples were prepared by coprecipitation from aqueous solutions of $\mathrm{Zn}\left(\mathrm{NO}_{3}\right)_{2}, \mathrm{Mg}\left(\mathrm{NO}_{3}\right)_{2}$ and $\mathrm{NaWO}_{4}$ at room temperature. Cleaned and dried precipitates were mixed with lithium nitrate in a weight ratio of $1: 10$ and melted at $300^{\circ} \mathrm{C}$ followed by aging for $16 \mathrm{~h}$. The reaction product was washed, filtered and dried at $80^{\circ} \mathrm{C}$ in air.

For X-ray phase analysis Siemens D500 Powder Diffractometer $\left(\mathrm{CuK}_{\alpha}\right.$ nickel filter, Bragg-Brentano geometry) was used. The morphology of nanocrystals was studied by transmission electron microscopy (TEM) using EM-125 microscope (SELMA, Ukraine). The accelerating voltage was equal to $125 \mathrm{kV}$, the study was conducted in the bright field mode, the image was recorded by CCD matrix.

The luminescence spectra of nanocrystals were investigated by means of automatic spectrofluorimeter based on the MDR-23 monochromator. For registration of the luminescence spectra Hamamatsu R9110 photomultiplier operating in photon counting mode was used. Photoluminescence was excited by the third harmonic of YAG:Nd laser EKSPLA NL-202/TH $\left(\lambda_{\text {exc }}=355 \mathrm{~nm}\right)$, $\mathrm{X}$-ray luminescence was excited by REYS (anode voltage - $25 \mathrm{kV}$, heating current - 


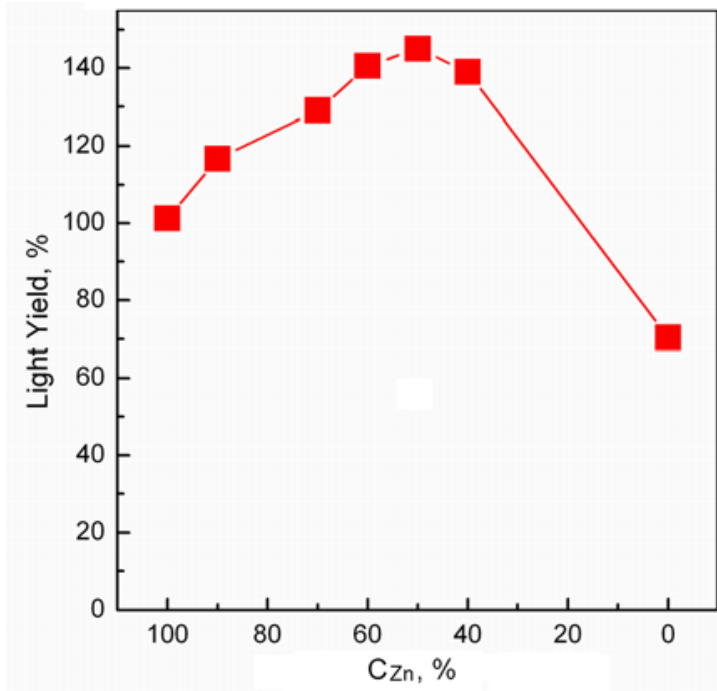

Fig. 2. The light output of $\mathrm{Zn}_{x} \mathrm{Mg}_{1-x} \mathrm{WO}_{4}$ bulk crystals with different composition.

$37 \mu \mathrm{A})$. The relative light output of the crystals with sizes of $\varnothing 15 \times 2 \mathrm{~mm}^{2}$ was measured at X-ray irradiation (anode voltage $200 \mathrm{kV}$, current - $1 \mathrm{~mA}$ ).

\section{Results and discussion}

XRD analysis has shown that all samples are monophasic and have monoclinic wolframite structure. Although all nanocrystals were obtained under identical conditions, samples of the starting compounds had smaller sizes as compared with the mixed nanocrystals. TEM images of nanocrystalline samples of $Z_{n W O}$ and $\mathrm{Zn}_{0.5} \mathrm{Mg}_{0.5} \mathrm{WO}_{4}$ are shown in Fig. 1. $\mathrm{ZnWO}_{4}$ had grain-like shape with dimensions of $40-100 \mathrm{~nm}$, $\mathrm{Zn}_{0.5} \mathrm{Mg}_{0.5} \mathrm{WO}_{4}$ was composed of larger grains with sizes up to $200 \mathrm{~nm}$.

The luminescence spectra of $\mathrm{Zn}_{x} \mathrm{Mg}_{1-x} \mathrm{WO}_{4}$ bulk crystals at $\mathrm{X}$-ray excitation consisted of the single band with maximum at $495 \mathrm{~nm}$, which is usually associated with the radiative relaxation of excitation in $\mathrm{WO}_{6}{ }^{6-}$ oxyanion complex involving electron transfer from the $5 d$ tungsten orbitals to the $2 p$ oxygen orbitals, traditionally described as a relaxation of the self-trapped exciton [20-22]. The peak position and the width of the luminescence band are almost independent on the composition of the mixed $\mathrm{Zn}_{x} \mathrm{Mg}_{1-x} \mathrm{WO}_{4}$ crystal [8]. The dependence of the light output of bulk $\mathrm{Zn}_{x} \mathrm{Mg}_{1-x} \mathrm{WO}_{4}$ crystal on the composition at $\mathrm{X}$-ray excitation is shown in Fig. 2 . There is an increase in the light output for mixed crystals with a maximum at $x=0.5$. The value of light output for the crystal with $x=0.5$ is $\sim 1.5$ times higher than that for $\mathrm{ZnWO}_{4}$ and 2.1 times higher than the one for $\mathrm{MgWO}_{4}$.

$\mathrm{X}$-ray luminescence spectra of mixed nanocrystals are presented in Fig. 3a. As for the bulk crystals, for nanocrystals at $\mathrm{X}$-ray excitation the band with maximum at $495 \mathrm{~nm}$ was observed. The intensity of $\mathrm{ZnWO}_{4}$ luminescence was slightly higher than the one for $\mathrm{MgWO}_{4}$, but the change in the intensity of $\mathrm{X}$-ray luminescence for mixed nanocrystals compared to $\mathrm{ZnWO}_{4}$ shows abnormally high values in comparison with bulk crystals. The dependence of the light yield of $\mathrm{Zn}_{x} \mathrm{Mg}_{1-x} \mathrm{WO}_{4}$ nanocrystals on
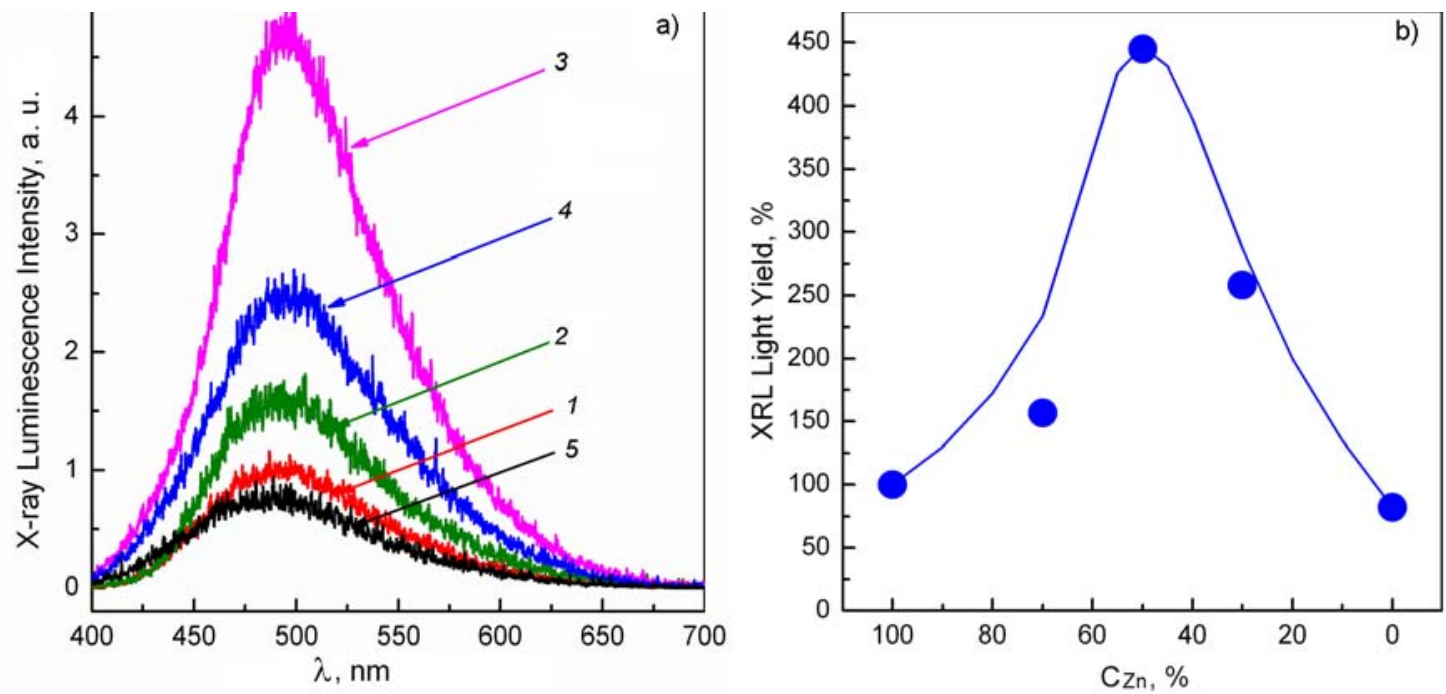

Fig. 3. X-ray luminescence spectra (a) and light output (b) of $\mathrm{Zn}_{x} \mathrm{Mg}_{1-x} \mathrm{WO}_{4}$ nanocrystals with different compositions: 1) $x=1,2$ ) $x=0.7,3) x=0.5,4) x=0.3,5) x=0$. 

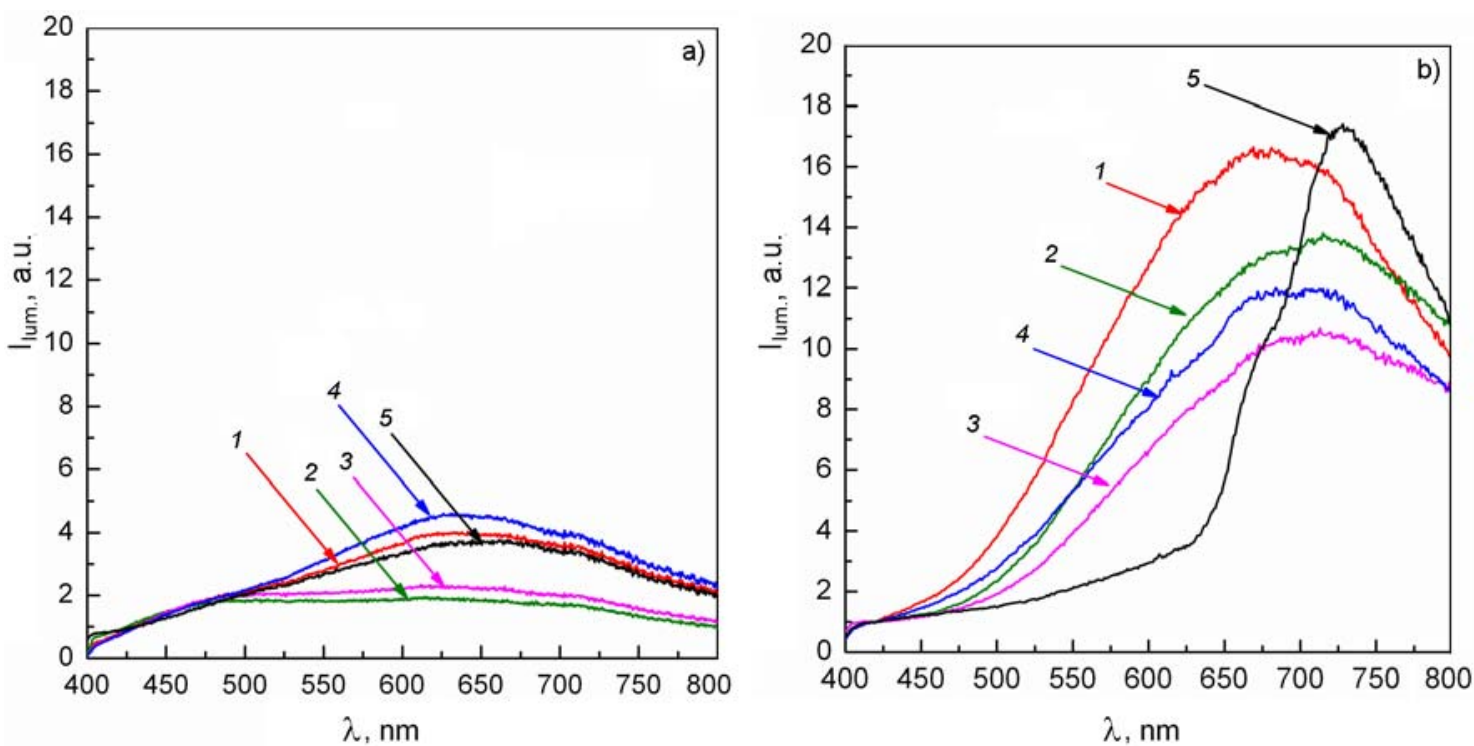

Fig. 4. Photoluminescence spectra at $\lambda_{\text {exc }}=355 \mathrm{~nm}$ for $\mathrm{Zn}_{x} \mathrm{Mg}_{1-x} \mathrm{WO}_{4}$ crystals (a) and nanocrystals (b) of different composition: 1) $x=1,2$ ) $x=0.7$, 3) $x=0.5,4) x=0.3$, 5) $x=0$.

their composition at $\mathrm{X}$-ray excitation is shown in Fig. 3b. For mixed $\mathrm{Zn}_{x} \mathrm{Mg}_{1-x} \mathrm{WO}_{4}$ nanocrystals the noticeable increase in light output as compared to their bulk counterparts was observed, with the maximum intensity (as well as the bulk crystals) for $\mathrm{Zn}_{0.5} \mathrm{Mg}_{0.5} \mathrm{WO}_{4}$ sample. While for the bulk $\mathrm{Zn}_{0.5} \mathrm{Mg}_{0.5} \mathrm{WO}_{4}$ crystal increase of light output relative to $\mathrm{ZnWO}_{4}$ was about $150 \%$, the value of light output for nanocrystals with similar composition exceeds that of $\mathrm{ZnWO}_{4}$ by $450 \%$.

Photoluminescence spectra of $\mathrm{Zn}_{x} \mathrm{Mg}_{1-x} \mathrm{WO}_{4}$ bulk crystals and nanocrystals at $\lambda_{\text {exc }}=$ $355 \mathrm{~nm}$ have shown a broad band with $\lambda_{\max }=$ $650 \div 720 \mathrm{~nm}$ ("red" band) (Fig. 4). For nanocrystals intensity of this luminescence band is sufficiently higher than for the bulk crystal (Fig. 4a and b). Intensities of the band with $\lambda_{\text {max }}=650 \mathrm{~nm}$ for $\mathrm{Zn}_{x} \mathrm{Mg}_{1-x} \mathrm{WO}_{4}$ crystals and nanocrystals of various compositions are shown in Fig. 5. While the intensity of the "red" photoluminescence band for bulk mixed crystals does not depend on the ratio of $\mathrm{Zn}$ and $\mathrm{Mg}$ cations, for nanocrystals of solid solutions nonlinear dependence with a minimum at $x=0.5$ is observed. This effect can account for noticeable increase of the light output of mixed crystals at transition to the nanoscale.

In [23] it was shown that the decrease in the intensity of the main X-ray band $\left(\lambda_{\max }=\right.$ $495 \mathrm{~nm}$ ) for $\mathrm{ZnWO}_{4}$ nanocrystals is accompanied by an increase in the intensity of the "red" luminescence band. In this case, the "red" band increases with decreasing

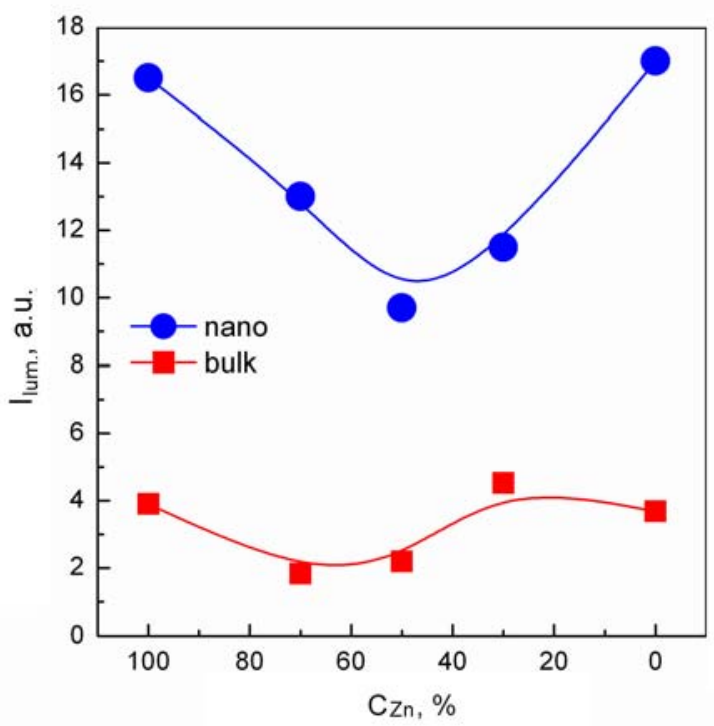

Fig. 5. Photoluminescence intensity $\left(\lambda_{\max }=\right.$ $650 \mathrm{~nm})$ for $\mathrm{Zn}_{x} \mathrm{Mg}_{1-x} \mathrm{WO}_{4}$ crystals and nanocrystals with different compositions.

$\mathrm{ZnWO}_{4}$ nanoparticle size due to increase in the concentration of oxygen vacancies and creation of distorted $\mathrm{WO}_{6}$ centers providing non-radiative relaxation channel competing with the luminescence of self-trapped excitons at X-ray excitation.

In the case of mixed $\mathrm{Zn}_{x} \mathrm{Mg}_{1-x} \mathrm{WO}_{4}$ nanocrystals dependence of $\mathrm{X}$-ray luminescence intensity on the composition with the maximum for $x=0.5$ is accompanied by the inverse dependence of "red" luminescence band intensity with a minimum value for $x=0.5$. Since the "red" band is associated with luminescence of distorted by oxygen 
vacancies $\mathrm{WO}_{6}$ centers that present nonradiative relaxation channel competing with the luminescence of self-trapped excitons at $\mathrm{X}$-ray excitation [23], one of the reasons for the abnormal increase in light output for $\mathrm{Zn}_{x} \mathrm{Mg}_{1-x} \mathrm{WO}_{4}$ nanocrystals can be a non-linear dependence of the oxygen vacancy concentration on the ratio of zinc and magnesium cations and its minimum value for $\mathrm{Zn}_{0.5} \mathrm{Mg}_{0.5} \mathrm{WO}_{4}$ sample.

\section{Conclusion}

The effect of light output increase observed for the mixed $\mathrm{Zn}_{x} \mathrm{Mg}_{1-x} \mathrm{WO}_{4}$ crystals with a maximum at $x=0.5$, increases substantially for nanocrystals with the same composition. This effect increases more than three times at transition to $\mathrm{Zn}_{x} \mathrm{Mg}_{1-x} \mathrm{WO}_{4}$ mixed nanocrystals. The change of the light output is accompanied by the nonlinear dependence on the ratio of zinc and magnesium cations of luminescence band determined by distorted tungstate complexes, with a minimum at $x=0.5$. This effect can be associated with the peculiarities of the processes of formation of oxygen vacancies in the mixed nanocrystals.

\section{References}

1. L.L.Nagornaya, B.V.Grinyov, A.M.Dubovik et al., IEEE Trans. Nucl.Sci., 56, 994 (2009).

2. H.Shang, Y.Wang, B.Milbrath et al., J. Luminescence, 121, 527 (2006).

3. P.Lecoq, A.Annenkov et al., Inorganic Scintillators for Detector System. Physical Principles and Crystal Engineering, Springer, New York (2006).

4. A.N.Belsky, E.Auffray, P.Lecoq et al., IEEE Tran. Nucl.Sci., 48, 1095 (2001).

5. Y.Wu, D.Ding, S.Pan et al., J.Alloys Compd., 509, 366 (2011).
6. K.Kamada, T.Endo, K.Tsutumi et al., Cryst. Growth Des., 11, 4484 (2011).

7. Nattasuda Yawai, Warut Chewpraditkul, Ongsa Sakthong et al., Nucl.Inst. Meth. Phys. Res. $A$, http://dx.doi.org/10.1016/j.nima.201 6.11 .036 (2016).

8. D.Spassky, S.Omelkov, H.Magi et al., Opt. Mater., 36, 1660 (2014).

9. N.Krutyak, V.Nagirnyi, D.Spassky et al., Rad. Measur. (2016). DOI - 10.1016/j.radmeas.2016.01.007 (2016).

10. Bing Yan, Fang Lei, J. Alloys Comp., 507, 460 (2010).

11. N.V.Klassen, V.V.Kedrov, V.N.Kurlov et al., IEEE Trans. Nucl. Sci., 55, 1536 (2008).

12. V.Pankratov, D.Millers, L.Grigorjeva et al., $J$, Phys.: Conf. Ser., 93, 012037 (2007).

13. A.G.Yakubovskaya, K.A.Katrunov, I.A.Tupitsyna et al., Functional Materials, 18, 446 (2011).

14. J.P.Reithmaier, L.Keldysh, V.Kulakovskii et al., Nature, 432, 197 (2004).

15. H.M.Shang, M.Bliss, S.Heald et al., J.Mater. Res., 22, 1527 (2007).

16. S.H.Yu, M.Antonietti, H.Colfen, M.Giersig, Angew.Chem. Int.Ed.Engl., 41, 2356 (2002).

17. P.Retif, S.Pinel, M.Toussaint et al., Theranostics, 5, 1030 (2015).

18. A.-L.Bulin, A.Vasil'ev, A.Belsky et al,, Nanoscale, 7, 5744 (2015).

19. F.A.Danevich, D.M.Chernyak, A.M.Dubovik et al., Nucl.Instr. Meth. Phys. Res. A, 608, 107 (2009).

20. V.Nagirnyi, E.Feldbach, L.Jonsson et al., Nucl.Instr. Meth. Phys. Res. A, 486, 395 (2002).

21. Cz.Koepke, A.Lempicki, J.Luminescence, 59, 33 (1994).

22. H.Kraus, V.B.Mikhailik, Y.Ramachers et al., Phys. Lett. B, 610, 37 (2005).

23. I.A.Tupitsyna, P.O.Maksimchuk, A.G.Yakubovskaya et al., Functional Materials, 23, 535 (2016). 